\title{
Effectiveness of Teacher Training Using Online Media During COVID-19 Pandemic in Indonesia
}

\author{
Dian Hidayati*, Rafiq Mubarak \\ Department of Education Management \\ Universitas Ahmad Dahlan, Indonesia \\ Yogyakarta, Indonesia \\ *dian.hidayati@mp.uad.ac.id, rafiqmubarak98@gmail.com
}

\begin{abstract}
During the COVID 19 pandemic, the Indonesian government implemented an online learning system. Teachers and students forced to be ready to do online learning. Teachers expected to improve their ability to adapt to online teaching and learning patterns. The training programs and seminars for teachers from March (the first case found in Indonesia) to September 2020 were carried out online by the government and the private sector. The purpose of this study was to determine the effectiveness of teacher training using online media during the COVID 19 pandemic. The method used in this study was descriptive research with a survey method. Respondents were 743 teachers from various regions in Indonesia who taught from elementary to high school levels. The instrument used was a Likert scale questionnaire distributed via a google form. The research instrument used consisted of 4 categories, namely a. Reactions (training satisfaction reactions such as presenters, time, means of providing), b. Learning; Knowledge, skills, and attitude, c. Behaviour: changes are applied daily, d. Result: (impact in daily activities). Based on the data, it shows that the implementation of teacher training through online media has been carried out effectively in terms of being relevant to work, increasing knowledge, obtaining benefits from training, and interacting with the presenters. The online training helped teachers to increase their teaching and learning ability.
\end{abstract}

Keywords-teacher training, online training, online media, Covid-19

\section{INTRODUCTION}

The COVID-19 pandemic which began in early March 2020 brought many changes to the world of education, including in Indonesia. Various countries have implemented social distancing restrictions to reduce more comprehensive virus transmission, from individuals who may be infected. However, they have not been identifying so that they are not yet isolated [1]. So that many school closings. The government policy to close educational facilities resulted in a change in the way of learning from face-to-face to online learning. This positively changing learning system has had a significant impact on the world of education. This learning change is a condition that requires entering information literacy in academic culture [2].
Online media in education is still an obstacle for teachers, which has an impact on success in the educational process [3]. Online media are now having an increasingly strong impact on teaching and learning processes, promoting techno-pedagogical practices and thus new training perspectives [4].

One of the causes of this significant change is that online learning is carrying out suddenly; this has a significant impact on the readiness of schools, teachers and students in carrying out inadequate learning. Moreover, the impact of the corona pandemic on the learning proses, that did not run optimally. They had to stay at home and apply physical distancing [5]. Teachers are required to adapt to this phenomenon immediately. The condition of some teachers does not understand about internet technology or the use of various online learning media, especially those in the regions. The results in less efficient learning, lack of student concentration and difficulty in understanding, asking and answering questions and discussing the material learned during online learning [6]. The need for teachers in facing online learning has led governments, universities, and other institutions to create training courses that held online. Online training, both paid and free, is in great demand by teachers. With so many trainings, it is necessary to pay attention to the effectiveness of the training. The characteristics of training effectiveness are reaction, learning, behaviour and results.

\section{A. Related Work}

Training is one of the methods which conveyed to the employee in the fulfilment of the organisational objectives. Organisations involved in the assessment of training effectiveness are not only responsible for what workers learn, but also need to ensure that the information learned by workers applied to their job results. Hence, training and its frequent assessment will undoubtedly render the organisation a leader in achieving the objectives

Method for measuring the effectiveness of training, which is generally recognised practised by many organisations is The Kirkpatrick Training Assessment Model. There consists of four stages [7]. According to this model, the evaluation should always start at the primary level, and further assessment of the 
other levels should be carried out based on the need for the situation. The four tiers shall include: Reaction-This defines how the trainees respond during the training phase. Learningthe degree to which learners develop knowledge and skills. Behaviour-the ability to execute the learning skills while at work. Results-includes things such as monetary, quality, morality.

An efficient teacher training programme should accompany any strategic shift in schools. Teacher training is an essential resource for improving the education system inclusive methodological approaches, curricular improvements and improving learning outcomes in foreign languages [8].

\section{B. Our Contribution}

This article provides some descriptions of the effectiveness of teacher training using online media so that it can provide information on whether online training can be practical or not.

\section{MethodS}

This study uses a survey method which conducted online using google form. The instrument used was a Likert scale. The data were collected using the saturated sample method. Data collection carried out by distributing questionnaires to 743 respondents as a sample consisting of elementary to high school teachers, both public and private schools from various regions in Indonesia. The research instrument used consisted of 4 categories, namely reaction a. Reactions (training satisfaction reactions such as presenters, time, means of providing), $b$. Learning; Knowledge, skills, and attitude, c. Behaviour: changes are applied daily, d. Result (impact in daily activities).

\section{RESULTS AND DisCUSSION}

\section{A. Results}

Teachers are currently learning through online and to improve their abilities in the teaching and learning process, they have attended several pieces of training held by the government, schools and other educational institutions.

\section{B. Discussion}

1) Reaction to training satisfaction: The basis of effective teaching with technology is the understanding that emerges from interactions among content, pedagogy, and technology knowledge [9]. The evidence shows that when teachers use their knowledge of both the subject and the way students understand the subject, their use of ICT has a more direct effect on the students' attainment [10]. In other words, "Digital competence is the teacher's proficiency in using ICT in a professional context with good pedagogic-didactic judgment and his or her awareness of its implications for learning strategies and the digital building of pupils" [11].

The online training media that teachers feel comfortable with can see in the following picture:

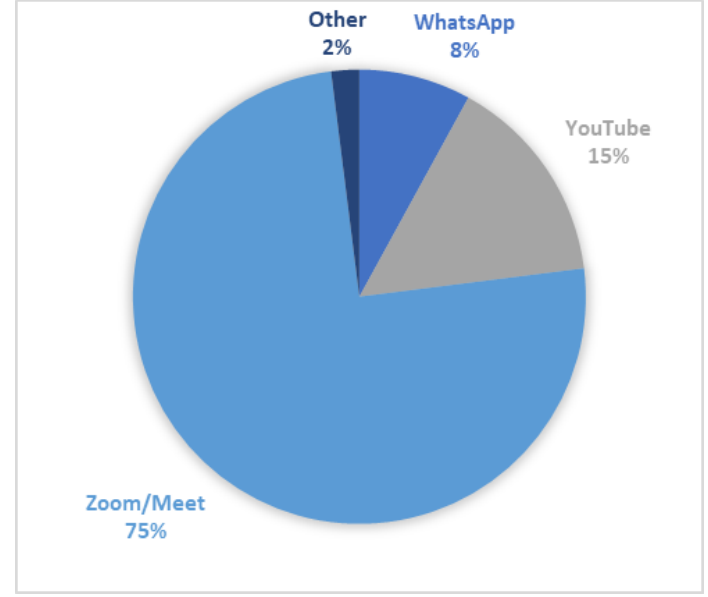

Fig. 1. Application used to teacher training.

Based on Figure 1, the teacher attended training through online media zoom/meet as much as $75 \%$ with the reason that the participants could meet face to face so that they could interact with the speakers. As many as $15 \%$ of teachers stated that using YouTube as a training medium because it can be viewing asynchronously, and the network used is more stable. Teachers who chose WhatsApp were as much as $8 \%$ because the internet costs incurred were cheaper than other media. Meanwhile, 2\% stated that media such as Google Classroom and other e-learning media are more comfortable to use as training media.

The training, which is carried out by many parties, both government and private, allows teachers to take part in many pieces of training or webinars. The data below can describe many training or webinars conducted by teachers via zoom or google meet.

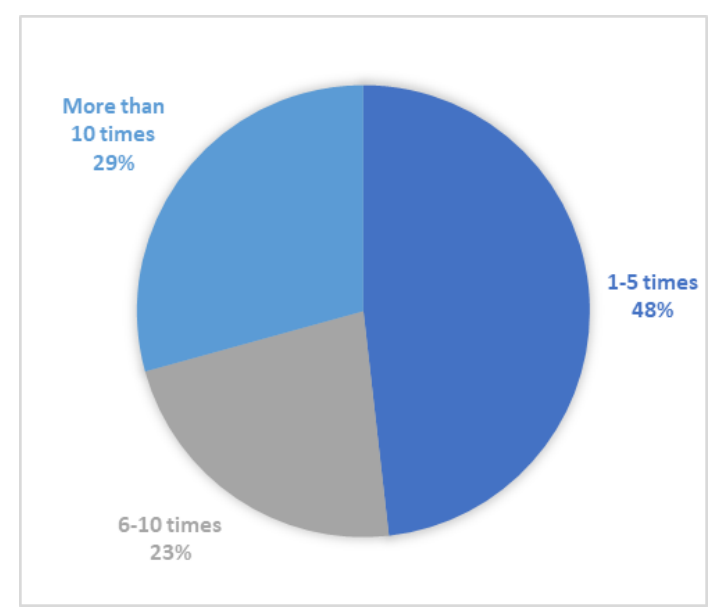

Fig. 2. Teacher online training using Zoom/ Google Meet.

Based on Figure 2, as many as 383 respondents stated that they attended training using Zoom/google meet more than six times. Meanwhile, as many as 361 people stated that they testified less than six times. 
The interaction between the presenters and participants using online media such as zoom/google meet felt by the teachers $37.3 \%$ good and $37.8 \%$ perfect. In comparison, $22.3 \%$ felt it was enough, $2.2 \%$ of respondents said the interaction was lacking, and $0.4 \%$ stated significantly less. The data illustrates that using video conferencing application media helps training participants interacting so that there is a good relationship with the training presenters

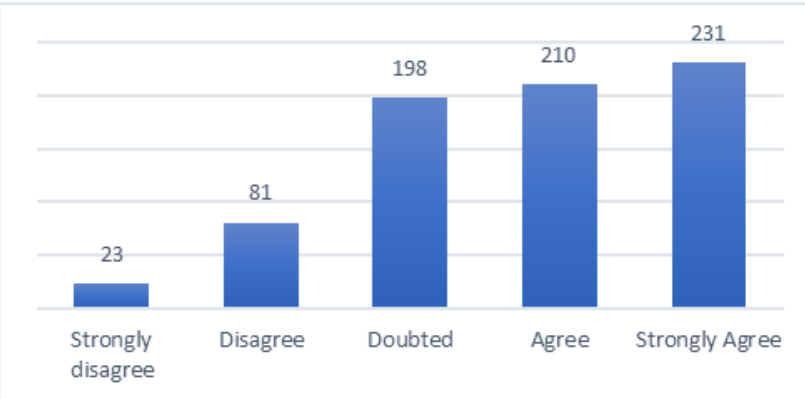

Fig. 3. Interacting between participate and trainer while online training.

Recruiters did not perceive the internet network constraints when participating in online training using zoom/google meet as many as $31.1 \%$ strongly agreed, $28.3 \%$ agreed, $26.6 \%$ doubted, $10.9 \%$ disagreed and $3.1 \%$ strongly disagreed (Figure 2). Respondents who stated that there were no obstacles stated that they had prepared themselves for the training, so they chose a place that had a good internet network. Meanwhile, respondents who disagreed stated that the network in their city was still not a good connection.

2) Learning (knowledge, skill, and attitude): The benefits of using online media in the learning process have a positive impact on increasing motivation during learning. Data supports the claim that the use of technologies in class increases motivation and curiosity for learning and improvement in the use of technologies [12]. Further reviews have shown that integration of ICT not only significantly improves practical knowledge of applications and programmes, but also contributes to developing skills and fosters an active and autonomous role of the [13]. Nevertheless, there is an increasing awareness among experts that, for potential attainment outcomes to be fully realised, ICT needs to be used to support subject learning and to impact on pupils' subject-specific learning processes [14].

Respondents responded that training using webinars using Zoom / Google Meet media helped to obtain the expected benefits as follows: $57.7 \%$ strongly agreed, $31.6 \%$ agreed, 9.7\% doubted, $0.5 \%$ disagreed and $0.4 \%$ strongly disagreed (Figure 4).

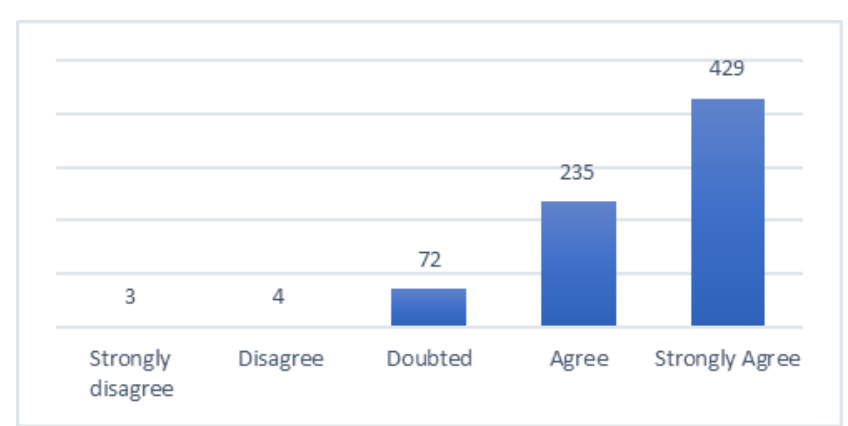

Fig. 4. Training using webinars Using Zoom / Google Meet media helped to obtain the expected benefits.

These data indicate that training through online / webinars using zoom/google meet can benefit as expected by the teacher. The following data is the level of knowledge obtained by participants or teachers, which can see in Figure 5.

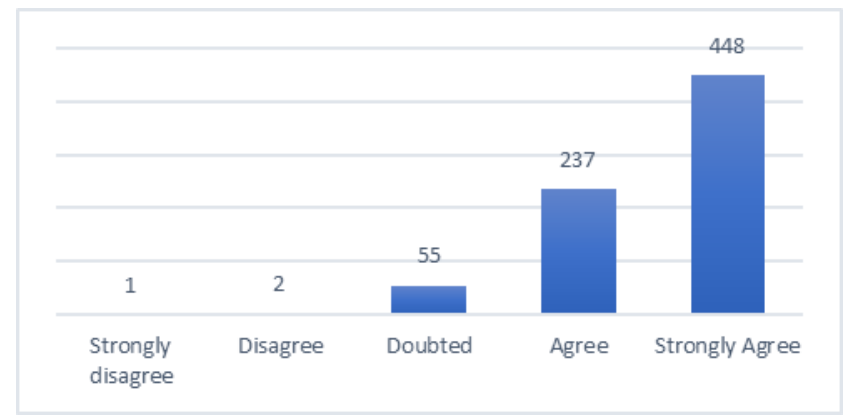

Fig. 5. Training through online / webinars using Zoom/Google Meet can benefit as expected by the teacher.

Respondents of $60.3 \%$ strongly agree, 31, 9\% agree and $7.4 \%$ doubt, while disagreeing and strongly disagree as much as $0.3 \%$ and $0.1 \%$.

The benefits obtained by respondents after participating in training activities can see from the data.

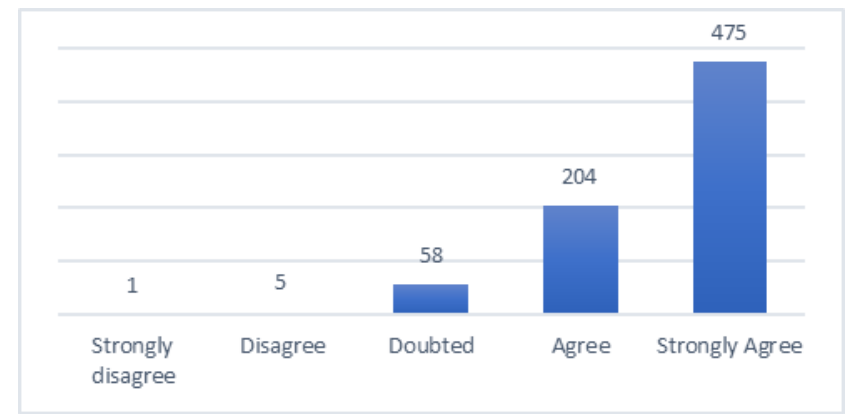

Fig. 6. The benefits obtained by respondents after participating in training activities.

The training carried out by respondents was felt to be useful for work as many as $63.9 \%$ strongly agreed, $27.5 \%$ agreed, $7.8 \%$ doubted, and the rest disagreed and strongly disagreed (Figure 6). Respondents stated that the training they had attended so far could be useful for their work as teachers. 
3) Behaviour (Changes in Daily Activities): After participating in online training activities/webinars, respondents can feel changes in teaching and learning activities, as shown in the data below:

a) Respondents can immediately use online learning without the help of others.

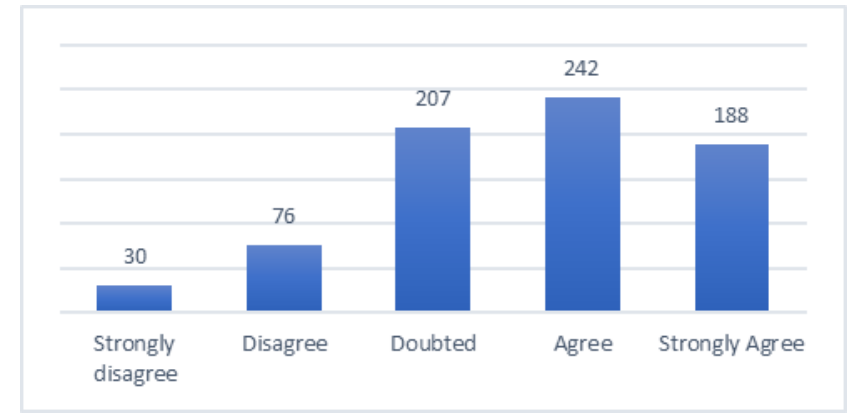

Fig. 7. Teacher immediately use online learning without the help of others.

Respondents stated strongly agree $25.3 \%$, agree $32.6 \%$, doubt $27.9 \%$, disagree $10.2 \%$ and strongly disagree $4 \%$. From Figure 7, 57.9\% that the training that followed can help respondents in carrying out online learning without the help of others.

b) Respondents follow the development of online learning applications as needed.

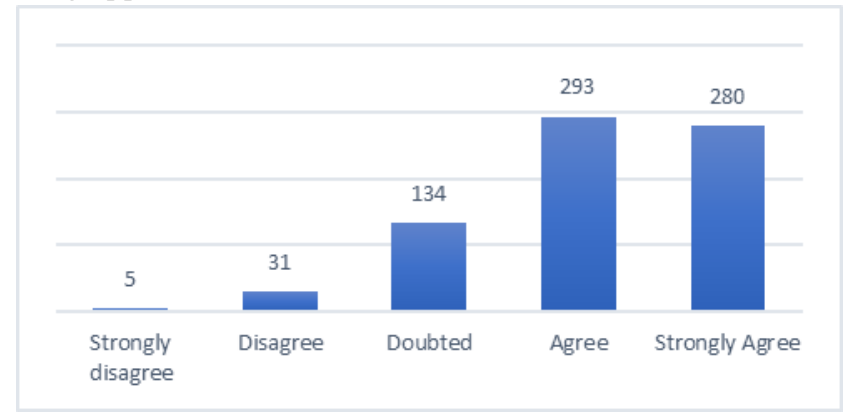

Fig. 8. Teacher follow the development of online learning applications as needed.

It can see from the Figure 8 , that $37.7 \%$ of respondents strongly agree, $39.4 \%$ agree, $13 \%$ doubt, $4.2 \%$ disagree and $0.7 \%$ strongly disagree if webinar training can increase the desire to follow the development of online learning applications as needed.

4) Result (Results from Training): The results of the training conducted by respondents so far have had several impacts:

\section{a) Contribution to better learning}

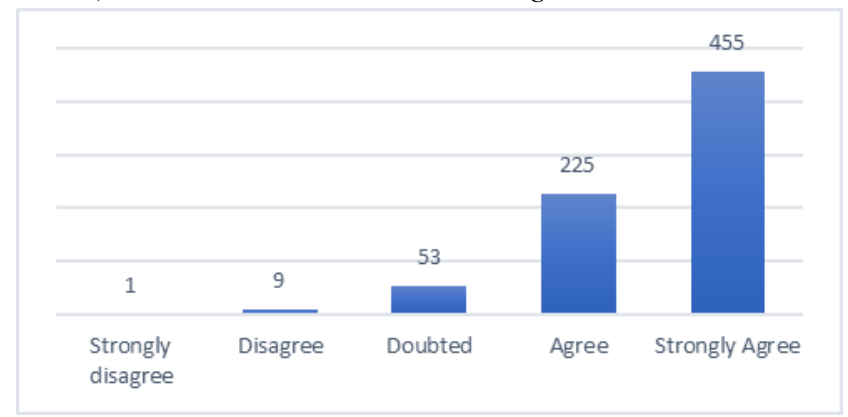

Fig. 9. The contribution of online teacher training to better learning.

Based on Figure 9, respondents stated that $61.2 \%$ strongly agreed, $30.3 \%$ agreed, $7.1 \%$ doubted, $1.2 \%$ disagreed and $0.1 \%$ of the training carried out contributed to better learning.

\section{b) Management of Teaching and Learning}

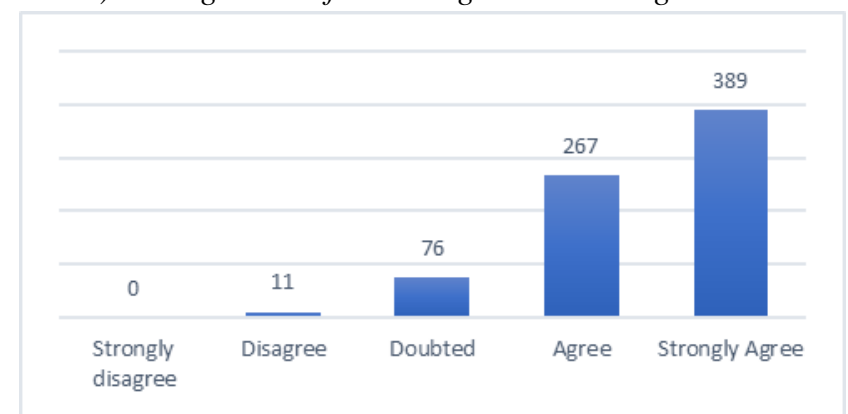

Fig. 10. Contribution of online teacher training to managing teaching and learning.

Based on Figure 10, after attending the online training, respondents stated that the management of learning was better $52.4 \%$ strongly agreed, $35.9 \%$ agreed, $10.2 \%$ doubted, $1.5 \%$ disagreed. So, it can be said that the training that the respondents did was beneficial in the management of teaching and learning.

c) Contribution on increasing teacher productivity in implementing learning process

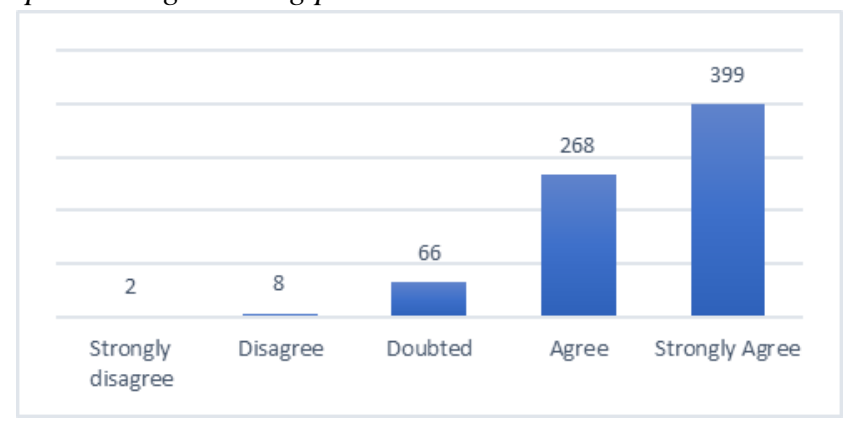

Fig. 11. Contribution of online teacher training to increasing teacher productivity in implementing learning process.

Based on Figure 11, in increasing teacher productivity in implementing learning, respondents strongly agree $53.7 \%$, 
$36.1 \%$ agree, doubt $8.9 \%$ doubt and $1.1 \%$ disagree. From this data, the training that was attended by the teachers had an impact on productivity when carrying out the learning process.

\section{CONCLUSION}

The results we obtained show that teachers seem very motivated in participating in training and want to improve their abilities in changing teaching patterns. The way schools organise training needs, training planning, evaluation and determining ways to acquire new skills.

With so many teacher trainings programs through online media, teachers have much access to improve knowledge and skills in teaching. The data shows that teachers are learning and applying knowledge and innovating in the classroom. So that the online teacher training program helps improve the teaching and learning process in schools.

\section{ACKNOWLEDGMENT}

This work supported by the Department of Educational Management Universitas Ahmad Dahlan Indonesia.

\section{REFERENCES}

[1] W. Darmalaksana, R. Hambali, A. Masrur, and M. Muhlas, “Analisis pembelajaran online masa wfh pandemic covid-19 sebagai tantangan pemimpin digital abad 21," Karya Tulis Ilm. Masa Work From Home Covid-19 UIN Sunan Gunung Djati Bandung, pp. 1-12, 2020.

[2] A. Hasanah, A. S. Lestari, A.Y. Rahman, and Y.I. Daniel, "Analisis aktivitas belajar daring mahasiswa pada pandemi Covid-19," 2020.

[3] E. Ifinedo, J. Rikala, and T. Hämäläinen, "Factors affecting Nigerian teacher educators' technology integration: Considering characteristics, knowledge constructs, ICT practices and beliefs," Comput. Educ., vol. 146, p. 103760, 2020.

[4] A.-J. Moreno-Guerrero, C. Rodríguez-Jiménez, G. Gómez-García, and M. Ramos Navas-Parejo, "Educational innovation in higher education: Use of role playing and educational video in future teachers' training," Sustainability, vol. 12, no. 6, p. 2558, 2020.

[5] A. Nursobah, U. Dedih, H. Hapid, and N. Nurhamzah, "Dampak pembelajaran daring terhadap penguatan literasi informasi dalam budaya akademik mahasiswa," 2020.

[6] D. Hidayati and W.A. Saputra, "Implementation of online learning during the covid-19 epidemic in Indonesia: Assessment of higher education students' use and implementation of online learning technology," Univers. J. Educ. Res., vol. 8, no. 10, pp. 4514-4519, 2020.

[7] D.L. Kirkpatrick, "Techniques for evaluating training programs," Train. Dev. J., 1979.

[8] R. Franco, "Generalitat de Catalunya Departament d 'Educació," p. 2005, 2005.

[9] M.J. Koehler, P. Mishra, and W. Cain, "What is Technological Pedagogical Content Knowledge (TPACK)?," J. Educ., vol. 193, no. 3, pp. 13-19, Oct. 2013, doi: 10.1177/002205741319300303.

[10] M.J. Cox and G. Marshall, "Effects of ICT: do we know what we should know?,” Educ. Inf. Technol., vol. 12, no. 2, pp. 59-70, 2007.

[11] R.J. Krumsvik, "Situated learning and teachers' digital competence," Educ. Inf. Technol., vol. 13, no. 4, pp. 279-290, 2008.

[12] J. Plaza and C. Caro, "La implicación de la familia en la formación ético-cívica de los jóvenes a través de las TIC," Aloma Rev. Psicol. ciències l'educació i l'esport Blanquerna, vol. 34, no. 2, pp. 97-106, 2016.

[13] J.M.S. López, "Valoración del impacto que tienen las TIC en educación primaria en los procesos de aprendizaje y en los resultados a través de una triangulación de datos/Assessment of the ICT impact in primary education in the learning processes and results," Rev. Latinoam. Tecnol. Educ., vol. 11, no. 2, pp. 11-24, 2012.

[14] D. Passey, C.G. Rogers, J. Machell, and G. McHugh, "The Motivational Effect of ICT on Pupils: A Department for Education and Skills Research Project 4RP/2002/050-3.," 2004. 